昭和39年 5 月（1964) J

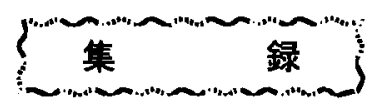

U.C.D. $620.199: 669.14 .018 .8$

\title{
ステンレス鋼の耐食試験法（1）
}

\section{Corrosion Test of Stainless Steels (1)}

会員稻垣修一

\section{1. まえがき}

ステンレス鋼は防食手段（防錆油塗布，ぺイ ント塗装、メッキなど）をはどてさずに腐食作 用の激しいところに使用されるものである。し たがって，その耐食性は常に問題視され，各種の 試験法が検討，使用されてきた。しかし腐食現 象に関与する要因は第 1 表のように多数あり， 材料側および腐食環境側要因が多数錯雑して影 㸷するため，実用試験ではデータの再現性が低 く，その普偏性はさらに乏しくなる。現場に役 立つデータを作る実用試験は実施困難な場合 （化学工場プラントなど）が多く，先に実験室

\section{第 1 表 笍食に関与する要因}

\begin{tabular}{|c|c|}
\hline $\begin{array}{l}\text { (1) } \\
\text { 材 } \\
\text { 料 } \\
\text { 側 } \\
\text { 要 } \\
\text { 因 }\end{array}$ & 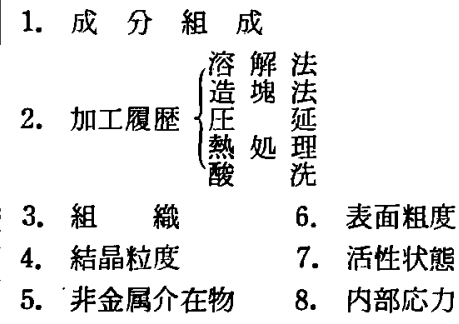 \\
\hline 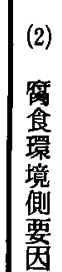 & 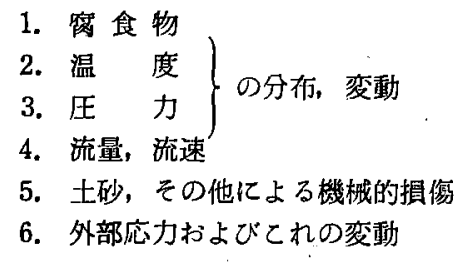 \\
\hline
\end{tabular}

的試験で材料の適性を把握するととが望まれる が，食現象に関与する因子は多く，てれの実 一験室的再現は困難である。また，てれの再現が
ある程度できたとしても，そのため個々に窝食 状況の実験室的再現をはかることはときに繁雑 であろう。そてで, 個々の場合を完全に满足さ せるものでないが，十分に満足する最大公約数 的データを実験室で得ることができれば，品質 管理, 適性の巨視的判定などには便利である。 この最大公約数的データを得る試験法が，規格 化されたものであると思われる。とてに，主と して規格を中心にステンレス鋼の耐食試験法を 集録し比較検討を加元た。

\section{2. ステンレス鋼の席食形寍}

ステンレス鋼の耐食性は，次の点で検討する ことが望まれる。

(1)：全面窗食：不働態性に支配される。

（2）粒界简食：粒界が選択的に简食され，結 晶粒の脱落を生し，侵食が非常に早く進行 する。

（3）点食：ハロゲンィオン共存の時発生。針 の先で突いたような深い穴が生ずる。

（4）応力雾食割レ：引張応力と盆食物とが共 存して発生。材料は, 非常に早く破断し, またクりープ現象は認められない。

（5）接触䆚食：罢種金属または非金属との接 触点が電池作用により窗食されること。

（6）機械的窗食：キャビテーション，エロー ション，擦過腐食など，パィプやスクリュ 一など輸送機関係の部分や高い玨力で接触 している面に認められる。

(7) その他

以上のうち，試験法が現在規格化されている ものは(1)〜(3)である。しかし，規格化されてい 
ないものは試験の必要性がないのではなく，例 えば応力腐食割レはステンレス鋼の宿命として 無視できない現象であるが，それが複雑である ため，いまだ規格化されていない。

\section{3. 耐食試験法}

\section{1 全面屚食}

\subsection{1. $5 \%$ 硫酸腐食試験}

ステンレス鋼（JIS G4303～4309-1964）に よれば, 棒, 板 (熱, 冷延) および帯（熱, 冷 延）の $5 \%$ 硫酸腐食試験は, SUS 32，33，35 および 36 のみについて行ない，試験はつぎに よる。

(1) 試験片

棒 ; 棒の断面に平行に切削してとり，その寸 法は厚さ $5 \sim 8 \mathrm{~mm}$, 直径 $15 \sim 30 \mathrm{~mm}$ （直径の小 さいものは原径のまま）とする。ただし平鋼の 場合は原則として厚さは原厚のままとし，15〜 $30 \mathrm{~mm}$ 角に切断する。この場合, 試験片の切削 総面積は試験片表面積の $1 / 2$ をてえないてとを 原則とする。

板; 武験片は板より切削してとり，その寸法 は15 30mm 角とし, 試験片の切削総面積は, 試験片表面積の 1 \%ををこえないことを原則とす ろ。

帯; 武験片は, 帯より切削してとり，その寸 法は $15 \sim 30 \mathrm{~mm}$ 角とし, 試験片の切削総面䅡 は，試験片表面の $1 / 2$ 市こえないことを原則と する。

試験片の表面は, JIS R6252(研摩紙)または JIS R6253(耐水研摩紙)の規定による500 番ま で研摩し，最後は必ず新品の研摩紙で数回研摩 する。

(2) 試験方法

1）試験前の試験片の清浄と重量測定; 試験 片の脱脂後アルコールおよびテーテルで洗浄し デシケータ中に 2 時間以上放置したのち重量を 測定する。

2）試験装置; 武験装置は，十分な冷却面積 をもつ立形の逆流コンデンサー付きすり合わせ フラスコ（容量 $1 \ell$ ）と, 試験中試験液を沸榺 状態に維持する加熱装置を使用し, 試験片は,
適当なガラスホルダにより液深の妇位に保持す る。

3）試験液；5％（重量）硫酸溶液は，JIS K8951 (硫酸) 1 級品以上と蒸留水または脱イ才 ン水から調製し，その濃度許容範囲は5.0士0.1 $\%$ とする。試験液の量は, 試験片の面揹 $1 \mathrm{~cm}^{2}$ 当り $25 \sim 30 \mathrm{ml}$ とする。

4）試験時間; 試験片は，液の沸鶿開始後装 入し, その時刻から沸騰連続 6 時間の試験を行 なう。

5）腐食減量；試験後，試験片は室温の30\% 硝酸（JIS K8541，1 1 級品）で洗浄し，水洗乾 燥後デシケータ中に放置してからその重量をは かり，减量の単位面皘，単位時間当りの檤を $\mathrm{gm}^{2} \mathrm{hr}$ で算出する。简食減量は第 2 表によ る。

第 2 表

\begin{tabular}{|c|c|c|c|}
\hline 種 & 記 & 㔯 & $\begin{array}{c}\text { 瓷食 減 量 } \\
\mathrm{g} / \mathrm{m}\end{array}$ \\
\hline 32 種 & S US & 32 & 5.5 以下 \\
\hline $33 \prime$ & $"$ & 33 & $4.5 \prime \prime$ \\
\hline $35 "$ & " & 35 & $4.5 \quad$ " \\
\hline $36 "$ & "I & 36 & $3.5 "$ \\
\hline
\end{tabular}

ただし，試験片は $1010 \sim 1150^{\circ} \mathrm{C}$ 急冷によ り，固溶化熱処理をした状態のものとする。な お，冷䦩引抜き，研削，切削またはてれらの組 合わせにより製造した棒は，とくに指定のない かぎり熱処理を施さない。

\section{2 粒界席食}

\section{2 .1 硫酸 - 硫酸銅粒界窝食試験}

ステンレス鋼（JIS G4303〜09-1964）によ れば，棒，板 (熱・冷延)，帯（熱・冷延）の 硫酸・硫酸銅粒界倠食試験は, SUS 28, 29, 33 および 43 種のみについて行ない，試験はつぎ による。

\section{（1）試験片}

棒; 試験片は厚サ $5 \mathrm{~mm}$ まで軸方向に片面を 切削してとり，その寸法はウ $25 \mathrm{~mm}$ 以下，長さ $30 \sim 70 \mathrm{~mm}$ とする。

板; 試験片は板より切削してとり，その寸法 は，厚节 $5 \mathrm{~mm}$ 以下， 巾 $10 \sim 20 \mathrm{~mm}$ ，長サ $30 \sim$ 
$70 \mathrm{~mm}$ とする。ただし，厚さ $5 \mathrm{~mm}$ をとえるも のについては片面を切削する。

带; 試験片は带より切削してとり, その寸法 は, 厚サ $5 \mathrm{~mm}$ 以下, 巾 $10 \sim 20 \mathrm{~mm}$, 長廿 30 $70 \mathrm{~mm}$ とする。ただし，厚サ $5 \mathrm{~mm}$ をと元るも のについては片面党切削する。

試験片は研摩前に $650^{\circ} \mathrm{C} ， 2$ 時間加熱空冷を 行ない, 試験片にスケールが付着している場合 は，機械仕上げを行なって除去したのち，曲げ 面の凸側の頂きにあたる部分を JIS R6251

(研摩布), JIS R6252 (研摩紙), JIS R6253 （耐水研摩紙）または JIS R6254（エンドレス 研摩ペルト）の規定による 220 番以上で研摩す る。

\section{(2) 試験方法}

1）陚験前の試験片の清浄；試験片のゴミお よび油脂は，適当な溶剂または洗剤で除去す る。

2）試験装置; 武験装置は, 十分な冷却面積 をもつ立形の逆流コンデンサー付きすり合わせ フラスコと, 試験中試験液を沸騰状態に維持す る加熱装置を使用する。

3）試験液および銅片;硫酸・硫酸銅溶液は, JIS K8983（結晶硫酸銅）1級品以上 $100 \mathrm{~g}$ t 蒸留水または脱イオン水 $700 \mathrm{ml}$ 亿溶解し，

JIS K8951（硫酸 1 級品以上） $100 \mathrm{ml}$ を加えて $1000 \mathrm{ml}$ にうすめる。試験液中には，十分な裴 面積を有し，試験中試験片と接鳋させ，試験終 了後も残存する量の JIS H3101 (銅板) 2 級相 当品以上を添加する。試験液の量は, 試験片の 表面積 $1 \mathrm{~cm}^{2}$ 当り $8 \mathrm{ml}$ 以上とし, 試験片を完 全に浸漬させる。なお，同一鋼種については， 同一容器で液量の許す限り試験片の数に制限な く, 試噓してもよい。

4）試験時間; 試験片は液の沸腾開始後装入 し, その時刻から沸騰連続 16 時間の試臨を行 なう。

5）曲ゲ試験；沸騰試験後試験片は板の表面 を外側にして内側半径を厚サの 0.5 倍で $180^{\circ}$ 屈 曲し, 曲ゲ面の外側の頂きを拡大鏡 (5〜15) 倍 にて観察し，粒界腐食による割レの有無を調へ
る。

判定しにくい場合は顕微鏡（100〜250倍）を用 いる。なお，試䀫片の端面から生じた割レなら びに割レをともなわない滑り線，しわおびよ肌 あれは，粒界腐食割レとは認めない。

6) 判定

硫酸銅粒界食試臨による曲げ面の状態は第 3 表に示す。

\section{第 3 表}

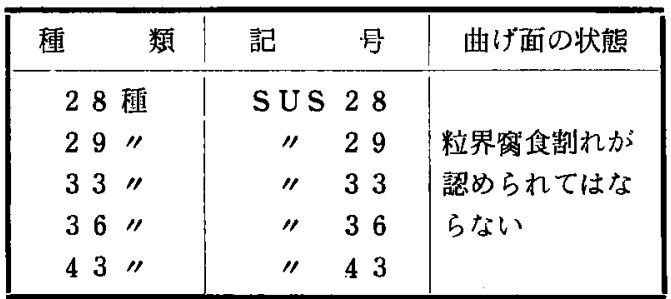

$3 \cdot 2 \cdot 2$ オーステナイト系ステンレス 鋼の電 導性酸性硫酸銅粒界窝食試験推薦試案〔ASTM A393-55T (1955)]

1. 適用範囲

(a) 乙の推闖試案はオーステナイト系ステ ンレス鋼の粒界简食感受性の測定に用いる電導 性酸性硫酸銅試腐方法を規定するものである。 この試験による瓷食の有然は，必ずしも他の窝 食環境における材料の成積を示すものではな い。

（b）この試験は，「受取のまま」の材料に 実施した熱処理を評価するのに使うことがあ る。また，粒界窗食を防ぐ安定化または低 C （最大 $0.03 \% \mathrm{C}$ ）ステンレス鋼の効果を評価す る場合に用いる。

（c）乙の推䳸試案は，オーステナイト系ス テンレス鋼の加工留品（管を含む），錆物およ び溶接材に適用するものとする。

2. 装置

（a）容器; 酸の蒸発愪失を防止するように コンデンサを付けた適当なガラスまたは他の不 侵食性容器を，酸性硫酸銅溶液に用いる。301 ンチの逆流コンデンサまたは耐食鋼の沸騰硝酸 試験(ASTM A262)に使用するような球状コン デンサ付き容量 11 , 広口の三角フラスコ（**) 
がよい。コンデンサを使うときは、フラスコの 連結にはすり合わせを使うのがよい。ゴムやコ ルク栓は不適当である。

（b）試験片保持; フラスコ内で武験片を保 持するのに，ガラス製フックあぶみ，または かごを使用する。その形状は，同一容器内で武 験するとき, 試験が互いに接触しないようなも のでなければならない。

（c）加熱器; 試験液を試鈳期間中加熱し, 沸茜を続けるととを目的とする。ガスまたは霆 気で加熱する血状のものがよい。

3. 試薬

酸性硫酸銅溶液*

硫酸銅 $\left(\mathrm{CuSO}_{4} \cdot 5 \mathrm{H}, \mathrm{O}\right) \quad 100 \mathrm{~g}$ 蒸留水 $700 \mathrm{ml}$ に溶解し, 硫酸 ( $\left.\mathrm{H}_{2} \mathrm{SO}_{4}, \mathrm{~d}=1.84\right) 100 \mathrm{ml}$ を 加えて, $1000 \mathrm{ml}$ になるまで蒸留水を加える。

* この溶液は，およそ無水 $\mathrm{CuSO}_{4} 6 \%$ および $\mathrm{H}_{2} \mathrm{SO}_{4}, 16 \%$ （重䭪）を含む。

4. 試釦片

(a) 寸法

1）試験片の寸法および選択は，取引契約に 定めた，製品仕椂書または㡚買者および売渡人 間の合意代基いて指定するものとする。その 際，使用する液量，製品は加工状態かまたは鋳 造状態か，試験の選択法および検查のための試 験片の曲ゲ方法を考虑すべきであうう。試験片 の寸法は，かなり口のせまい三角フラスコでも 出し入れが容易でなければならない。

2）溶接試験片は，溶接電極をおおった耐食 クロムおよびクロム・ニッケル銅の組成によっ て調製しなければならない（ASTM A298，第 IV 部)。

3）第4表に示す寸法は仲裁裁定の指針に使 用してさしつかえない。垁際の長サは，試験片 を曲ゲるのに使用する工具で定められよう。

** 鋳物や重い棒などより調较した試料には，大 きな三角フラスコを使うことが必要であろう。
第 4 表 䳝駼片の寸法

\begin{tabular}{|c|c|}
\hline 材 料 の 形 & 試験片の寸法 \\
\hline $\begin{array}{l}\text { 線材または棒 } \\
\text { 直径 } 1 / 4 \text { in以下 } . . \\
\text { 直径 } 1 / 4 \text { in以上. }\end{array}$ & $\begin{array}{l}\cdots \text { 原径 } \times 3 \sim 5 \text { in 長サ } \\
\cdots 1 / \text { in 厚 } \times 1 \text { in }(\max ) \text { 長サ } \\
3 \sim 5 i n \text { 長サのかまばこ形 }\end{array}$ \\
\hline $\begin{array}{l}\text { 薄板, 带, 带また } \\
\text { は平らな压品 } \\
\text { 厚さ } 3 / 16 \text { in以下 } . . \\
\text { 厚さ } 3 / 16 \text { in以上… }\end{array}$ & $\begin{array}{l}\ldots \text { 原厚 } \times 3 / 8 \sim 1 / 2 \text { in 巾 } \times 3 \sim \\
5 \text { in 長サ } \\
\cdots 3 / 1 \text { sin 璟 } \times 3 / 8 \sim 1 / 2 \text { in } \times 3 \times 3 \\
\sim 5 \text { in 長サ b ) }\end{array}$ \\
\hline 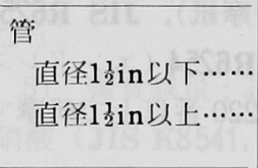 & $\begin{array}{l}\cdots \text { 完全円 } \times 1 \text { in币 c ) } \\
\cdots 1 \text { in 巾の環から切り取った } \\
\text { 部分円 d ) }\end{array}$ \\
\hline 鋳物 e ) .... & $\begin{array}{l}\cdots 3 / 1 \text { in 厚 } \times 3 / 8 \sim 1 / 2 \text { in } \times 3 \\
\sim 5 \text { in 長サ }\end{array}$ \\
\hline
\end{tabular}

〔註】 a )てのような試験片を曲げるときは，曲面を 曲ゲの外側こする。

b） 1 面は材料の原面とし，それを曲げの外側とす る。こ扎は第 4 節 (c) 1) にのへだ様に仕上げ るものとする。冷延带または澍板は「受取まま」

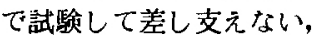

c）円部分は試験液に浸す前に，平らにするとかま たは機栈加工を加えないものとする。

d）直径 $11 /$, in 以上の溶接管汃らつくった試験片 は, 曲げ軸上に溶接部分をとるものとする。

e）竜骨台または実際に鋳物の外側表面に近い所加 ら機栈加工で作つた試験片

（b）切り口

武験片をシャー切断した時は，切断粶は試験 前に機械加工または湿式グラインダで精削する ものとする。

(c) 表面仕上

1）「受取のまま」で表面上のスケールは機 械仕上で除去しなければならない。特殊の表面 仕上を有する試験片（冷延帯または薄板は受取 のまま）に要求されるもの以外は，試験片の全 表面を緑专含めて 120 番粒度の鉄分のない酸化 アルミニウム研摩紙により，加熱しないように 仕上げるものとする。

2）清净; 試験片は，アセトン，アルコール とエーテルの混合物または蒸気脱脂剤のような 適当な溶剤により脱脂し，乾燥するものとす る。 
（d）センシタイズ熱処理

1）「受取のまま」材料「受取のまま」条件に 入る材料はすべてての試験に入りうる。

2）安定化および低C 型安定化材料わよび最 大 $0.03 \% \mathrm{C}$ 型の粒界烄食防止の効果の判 定に 必要であろう。次の熱処理条件は，すべての種 類の材料に使用する。: $1250^{\circ} \mathrm{F}\left( \pm 25^{\circ} \mathrm{F}\right)\left(676^{\circ}\right.$ C) 大気中 $1 \mathrm{hr}$ 後空冷

〔注〕1，大気中で試駼片を加熱する方がよい。浸岸 化登囲気中や高C鋼または炭素と接触した状態で 処理してはならない。

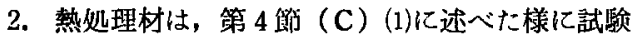
前にスケールを除去し仕上ゲるるのとする。冷延 薄板または州からつくった試駼片は「センシタイ ズ」条件で試験してさしつかえるい。

5. 試験条件

（a）液量；酸性硫酸銅試験液は試験片をお おうようにして，試験片の単位表面積当り少く とも $50 \mathrm{ml} / \mathrm{in}^{3}\left(8 \mathrm{ml} / \mathrm{cm}^{2}\right)$ を準借し, 十分に 使用するものとする。

(b) フラスコ当りの試験片の数

各試験片毎に容器 1 個を使用することが最も よい方法である。しかし，同一鍊種のものに限 りまた試験片を互いに接触しないように保持 し, 液量の面積当りの此率を保つなら同一容器 に 3 個までの試験片を入れてよい。もし，同一 フラスコ内で試験した試験片が不合格の時は不 合格材から取った新しい試験片を各個に再試験 するものとする。

\section{(c) 沸騰時間}

1）陚験片を試験片に浸けてから沸䐜*させ, 試験期間中沸騰させなければならない。

* 沸腾中の溶液の「突沸」は, ガラス球, 素跰の かけら，アルミナ管または沸腾石を使えば小さく なる。

2）試験は，他に規定のない限り，72時間沸 騰 1 週期**よりなるものとする。

** 72時間沸滕 1 週期以上の規定あ万時は, 各週期 毎に試医液を更新しなければ

6. 曲ゲ試験

(a) 曲ゲ

1）試験片は通常板厚または棒の径に等しい 径で $180^{\circ}$ に検查目的で曲げるものとする。特に
冷延材の「受取のまま」条件の場合，試験片を 留品仕様㻎に明記したものより小さな半径むた は大きな角度で曲げてはならない。

肉厚鏻物は，粒億粗く，伸ビが低いので， $180^{\circ}$ 曲ゲはできない。伸ビが低い場合は 1 対の 試験片を材料からつくらなけれどならない。1 個の試験片は酸性 $\mathrm{CuSO}_{4}$ 液につけないで，曲 げ試験により割レを生じない最大曲ゲ角度を定 め，標準とする。試験液にさらした試験片を同 じ様に曲げて，その結果を比較する。

2）薄板試験片は，圧延材の抗張力試験片を 「S」字形に曲げたものとする。

〔注〕「S」字形風曲は，压延の最終工程で薄板材 の1方の面の浸炭による粒界浸食の検出走保証す る。

3）部分円または鋳造材から機械加工した試 料では，曲面または原面を曲ゲの外側とする。

4) 試験片は，普通は最初ハンマーで曲ゲて から，万力にはさんで曲ゲる。万力の両しめつ け端が付着した状態で普通は曲げたとする。重 ，い試験片は適当な形状の治具で曲ゲる必要があ る。

5）管は，製品仕様書に逃べた。奏際よりよ い結果を示す試験によって曲げるものとする。

〔注〕実際より良い結果を示す典型的な試験は, つ き目なし合金ボイラー，過熱機乩よび熱交换機用 管（A S TM A213）の仕梯䛐に述べてある。

(b) 評佂

。U字形曲ゲを 5〜15 倍の低倍率で検查するも のとする。さけ目または割レの存在が，粒界腐 食の存在を示す。

試験片の縁に生ずる割レは考慮しないものと する。変形線，しわ，または表面の「皮むけ」 がわれ，またはさけ目をともなわずに存在す る場合も考慮しないものとする。

〔注〕仆裁々定として上の評価か疑わしい特には, 粒界侵食の有無を金属組織学的試験により, 試験 片の横断面を100～250倍で測定してよい。

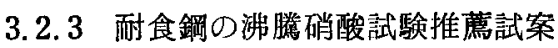

(ASTM A262--55T (1955)

1. 適用範囲 
沸騰硝酸試験に関する本推箐案は，耐食鋼の 品質，殊に熱処理の効果を調查するためには， 最も有用かつ信頼し得る方法であるととが知ら れていた。従来品質管理および検查試験に使朋 され，また耐食鋼の成分，留法および処理の改 良苍目指す研究に益を与えてきた。試跧条件と 直接に関係のない実用状態の耐食鋼の適性の予 知に使用するつもりはない。

2. 装置

装置は次のものからなる。

（a）容器; 硝酸試験溶液には蒸発による酸 の賣失を防止するようコンデンサをつけた適当 な容器* 30一in コンデンサまたは第 1 図に図 示する様な球形コンデンサのどちらかをつけた 容量 11 の三角フラスコが満足すべきものであ （c）加熱器； 試㙠期間中試釦液を加熱沸 睛させておくには，需気加熱板がての目的には 満足すべきものである。

（d）多数試片試験装置; 多数の試験片を 試験する洔には，特にこの目的に設計し，1時 亿試験片 40個考収容しうる多数陚片試験装置を 使詡してさしつかえない。この装置の主要部分 は底部に䤡物のカッブをつけ，また第 2 図に示 すようにステンレス鎆製コンデンサを組み付け たスチーム加熱方式のケイ素鉄製釡である。精 製された㠜縮した酸はコンデンサよりカップに したたり落ち，そこより釜の月の底部にある多 量の酸の中へあふれ出す。毎時カップ約 4 杯の 速サでカップから再蒸留酸が流れる時が, カッ プの中の酸の中の篦食生成物の漶度は從来の試 跧装置に見られたものよりも常 時少いであろう。試験片と接触 する酸の中の窗食生成物の堆積 が少いために，多数試験装置で 得た窝食速度は，従来の装置で 試験片一枚を使って得たものよ り常に低い。

（e）天科；化学天科では 試片の総面皘 $50 \mathrm{in}^{2}\left(323 \mathrm{~cm}^{2}\right)$ またはそれ以下の場合はほほ $0.001 \mathrm{~g}$ まで，また更に大きな 試片については，陚片の面積を 平方インチの場合は 50 で割り

る。コンデンサを使用する場合は，てれとフラ スコの連結にはスリガラスショイントを使用し なければならない。ゴムまたはコルク栓は不適 当である。

（b）試験保片持; フラスコ内で試試片を保 持するガラス製フック，あぶみ，またはかでは 試験中常時十分に溶液に浸り，また同一容器内 で試験した試験片が互いに接触しない様に設 計する。

* 蒸気の中の酸の検出はコンデンサーの口に青色 リトマス紙をあてておけばよい。もし，武験紙の色 が赤変するようであ机ば，冷水を増すか，または更 に大きな冷却器が必要であろう。
(試片の面䅡が平方センチであれば323で割る)

第 2 図多数試片試験装置

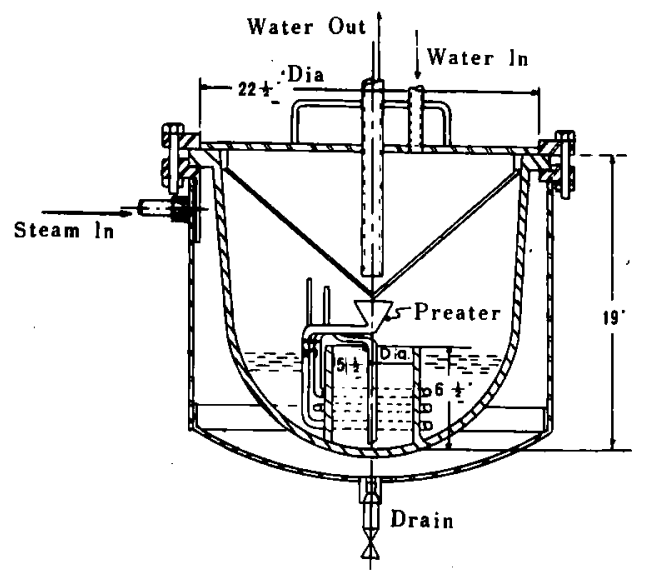


とれに $0.001 \mathrm{~g}$ をかけた程度まで科量する。

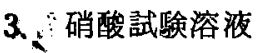

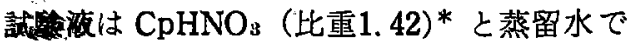
作り，分析に上り硝酸浱度が $65 \pm 0.2$ 重量\%に 調製しなければならない。試験に使用した後の 硝酸の最終濃度は，ときどきチェックしなけれ ばならない。

\section{4. 試験片の調整}

（a）試験片の寸法と形状は，正確な科量 （第2 節（b））と使用する試験片の便宣を考 虑しなければならない。さらに，棒，線，およ び管の場合は, 暴露している横断面の総面積に 占めろ割合が，結果に影響するであろう。その ような製品の試験片を研究調査に使用する場合 は暴露横断面の総面積に対する比は試験毎に一 定にしなけれぱならない。検查武験では，棒， 線あるいは管から切り取った試験片は，暴露し た横断面の面積は試験の総暴露面積の 2 分の 1 を越えないよう配分しなければならない。

（b）試験に先立ち試験片に特殊の熱処理を するとか，また溶接部のある試験片を使用する ことは，特に明記しなければならない。

（c）試験片をシャ一切断した時は，シャー 縁は試験に先立ち，機械加工またはグラインダ 研削で仕上げなければならない。

（d）試験片は, 寸法出し切断および表面仕 上げを除いて，受取り状態で式験しなければな らない。試験片上のスケールは，機械的仕上処 理に先立って化学的に除去しなければならな い。特殊の表面㤌上を有する陚片には要求され ないが, 試験片の全表面は, 縁も含めて, 乾燥

* 硝酸は,つぎのアメリカ化学協会の分析試薬に

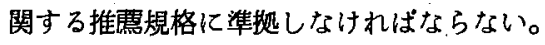

$\begin{array}{lll}\text { 不揮発性物質 } & \text { 最大\% } & 0.0005 \\ \text { S O+ } & \text { 最大 } \% & 0.0002 \\ \text { As } & \text { 最大 } \% & 0.000003 \\ \text { C1 } & \text { 最大 } \% & \text { 約 } 0.00007 \\ \text { 重金属 } & \text { 最大\% } & \text { 約 } 0.0005 \\ & \text { P b おょび } 0.0001 \mathrm{~F} \mathrm{e}\end{array}$

さらに，F含有量は $0.0001 \%$ を越えてはならず， またPOょは0.00002\%を越えてはならない。
No. 120 粒度の研磨紙を使って，熱が棌生しな い様にゆっくりと磨き，また各試験片とも最終 回は研磨紙の新しい部分を使って仕上げなけれ ばならない。

（e）試験片は寸法を測らなければならな い。またすべての穴の内側表面をも入れて表面 積を計算しなければならない。

（f）試験片は以上の操作の後，アセトン， 又はアルコールとェーテル混合物のような適当 な溶鼡**を使って脱脂し，乾燥および科量（第 2 節（e ))しなければならない。

（g）確性を目的とする試験では，試験片数 は各材料あるいは各材料のロットどとに 1 個の み使用するのが普通である。しかし，正確を期 する為には，少なくとも2 個の試験片を使用す ることを推める。

\section{5. 操作手順}

（a）試験片の硝酸は，十分に試験片がかく れる程，また試験裴面積当り少くとも $125 \mathrm{cc} /$ $\mathrm{in}^{2}\left(20 \mathrm{cc} / \mathrm{cm}^{2}\right)$ 使用しなければならない。

（b）各材料または材料の処理每に, 容器を わけるのが最もよい。しかし，試験片が同一鋼 種で耐食性が十分なものであれば，同一容器に 試験片 3 個まで入れて試験して差し支えない。 もし, 同一容器で試験した試験片のうち，1個 以上が不合格であれば， 1 個の試験片の過剩离 食がそれと一緒に試験した他の試片の窝食を促 進***したのであるから，試験片は容器をわけ て，再試験することが必要である。記録は，一

**とこに述べる清浄処理は，試験片を硝酸（20重 量パーセント) で, 120 より $140^{\circ} \mathrm{F} （ 48.89 \sim 60.00^{\circ}$ C）に20分間浸漬後，水洗，乾燥，およひ科量で補 足されよう。队側を其合よく表面清浄できない小径 管試験片の場合は，実際の試験と同一の装置を使用 して，沸䏯硝酸（65\%）に2時間浸漬の準備調整を 実地するのか望ましい。乙れらの処理の目的は，通 常の清浄法ではできない，また試験の初期の段階で は試験片にあきらかに重量減を生ぜしめる表面污染 の除去にある。調査研究者のなかには, 特有な表面 効果を除去し，また試験絬果の再現性を向上するた めにこの様な予倫酸処理を好む人もある。 
緒に試験した陚験片を表示する様にとらなけれ ばならない。

（c）試験片を, 容器の酸の中に入れてか ら，冷却水をコンデンサに流し，酸を加熱板上 で沸腾させて試験期間中沸䐘を続けなければな らない。試験期後に, 試験片を水洗し,それか らゴムまたはナイロンブラシを使って流水中で こすり洗い，付着した腐食生成物を除去しなけ ればならない。その後で乾燥，科量しなければ ならない。（第 2 節 $(\mathrm{e}))$ 乾燥は, 試験片をこ すり洗った後でアセトンに浸漬すればやりやす いであろう。

（d）試験は普通各週期とも新しい試験片を 使用して，沸鴬 48 時間 $\times 5$ 週期*からならなけ机 ばならない。相互の同意によって試験の経験よ り沸騰48時閒の3週期漂準試験を短縮しても よい。しかし，もしこの短縮試験操作で，第 3 週期の侵食速度が第 1 または第 2 周期を上回る 時は，試験は第 5 週期まで続行しなければなら ない。銅の船積み認可用検查試験に使用する洔 は, 操作は，次の沸騰 48 時間 3 週期で十分に実 施しうる事を, 沸騰 48 時間 5 週期の長時間試験 を十分に実施した上で認められれば，購買者と 製造業者とは合意してもよい。

\section{6. 計算と報告}

（a）計算一材料にわよばす酸の影響は，各 試験週期後の試片の重量減と, 試釦同期全般に ついての重量诚確認で測定しなければならな

**過剩窗食は, 試験夜の色変化で, しばしば倹出 される。その際は試験片が終らないうちに，試験片 毎に容器を分けるのがよい。

* 48洔間 5 週期試験のかわりに，48侍間 1 週期わ よび96時間 2 週期の組合せ（この順序でなくてもよ い)でも差し支えない。

客先向仕梯書の耐食銅の試験に 3 年以上この方法 を使ってきたある会社の報告によると，そこの笑験 室は，最初の 3 試而週期で得た笍食速度にもとづい て，船積み用に約 800 数件を許可してきた。また 5 週期式駼の最後の 2 週期では简食速度の異常による 失敗が生しなかったとある。
い。そのような重量減確認は第 2 節（e）で既

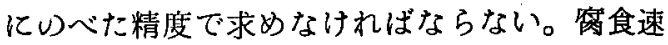
度は，次式で計算して 1 ケ月当りの侵食度をイ ンチであらわすものとする。

$$
\mathrm{R}=\frac{\mathrm{KW}}{\mathrm{AST}}
$$

ここで,

$\mathrm{R}=1$ カ月当りの侵食度をインチで表わした侵食速度 $\mathrm{K}=\mathrm{A}$ が平方インチの場合は43.9，あるいは $\mathrm{A} か ゙$ 平方 センチであれば283

$\mathrm{W}=$ 重量诚, $\mathrm{g}$

$\mathrm{A}=$ 総表面㮐，平方インチまたは平方センチ

$\mathrm{S}$ 二試料の密度 $1 \mathrm{cc}$ 当り $\mathrm{g}$

$\mathrm{T}$ 二試卧期間の継続澌間, $\mathrm{hr}$

* 上式化使用するステンレス銅ひ密度 $(\mathrm{S})$ は,下 㤗に示す。

\begin{tabular}{c|cc|c}
\hline $\begin{array}{c}\text { A S TM } \\
\text { 等級 } \mathrm{a}\end{array}$ & 銅 & 種 & $\begin{array}{c}\text { 密 } \\
\mathbf{g} / \mathbf{c c}\end{array}$ \\
\hline クロム鋼 & & & \\
6 & 446 & & 7.5 \\
2,4 & 410,430 & 7.7 \\
クロ & & \\
ニッケル鋼 & & & \\
$2,3,4$ & $302,304,308$ & \\
$8,10,5$ & $369,310,321$ & 7.9 \\
$11,12,6$ & $316,317,347$ & 8.0 \\
\hline
\end{tabular}

クロム鋼の等級には耐食クロム鋼板，薄板およひ 帯（A S TM A 176）の明細を含み, またクロム 一ニッケル鋼の等級は耐食クロムーニッケル鋼板, 㩐板および帛（ASTMA 167）の明細を含む。

（b）報告一結果は，3 週期あるいは 5 週期 の平均とともに，各週期の值も報告しなければ ならない。

〔注〕7一垹騰硝酸で高い窝食速度を示も試跧片 は，粒界的には侵食されていないであろう。従って 窝食速度を高く示す試験片に，粒界侵食の有無の確 認に金属組蟣学的检查をすることが锥告される。乙 の榆查は試酫の必須の要求ではない。

(以下次号) 